\title{
Features of Vertically Integrated Agribusiness Corporations in Western Europe Countries
}

\author{
Zakharova Elena Nikolaevna $^{1}$, Kerashev Anzaur Aslanbekovich ${ }^{1} \&$ Mokrushin Aleksandr Aleksandrovich ${ }^{1}$ \\ ${ }^{1}$ Adyghe State University \\ Correspondence: Zakharova Elena Nikolaevna, University of Anbar- Univrsity Malaysia Pahang, E-mail: \\ zahar-e@yandex.ru/kerashev@mail.ru/mokrushin_alex@inbox.ru
}

Received: December 29, 2014

Accepted: January 12, 2015

Online Published: July 30, 2015

doi:10.5539/mas.v9n8p417

URL: http://dx.doi.org/10.5539/mas.v9n8p417

\begin{abstract}
In order to ensure the region's population with food promising direction of development of agro-industrial complex is the vertical integration. The article summarizes foreign experience of vertically integrated structures formation in the agro-industrial complex. Special emphasis is made on the methods and ways of small agriculture producers' integration into agro-business. Authors studied the indexes of the current condition and agro-industrial complexes (AIC) development tendencies in the EU countries, agro-holdings dynamics, as well as the structure of used farmland in the EU countries. Authors also present the results of the largest multinational corporations' activity, formed due to active integrating processes in agro-business sphere. Authors underline the peculiarities of integration bonds formation in the EU countries' agro-industrial complex. The author believes that the further development of the vertical integration depends on the process of institutional mechanisms perfection. They provide the enlargement of small farms' participation in the present-day AIC market.
\end{abstract}

Keywords: agro-industrial complex (AIC), agribusiness, vertically integrated structure, agro-holding, agro-industrial integration, farm households

\section{Introduction}

\subsection{The Concept and Essence}

Agro-industrial complex (AIC) is one of the main generators of employment and profit and plays the major role in food provisions manufacture and the problems of undernourishment solvation. Agro-industrial complex is a combination of industrial branches dealing with production, processing and sale of agricultural products as well as of the branches serving functioning of agricultural enterprises including agricultural machinery. Agro-chemical manufacture, melioration branch and so on.

The term 'agro-business' stands for collective entrepreneur activity in the sphere of agro-industrial complex (AIC), including supply of agricultural raw materials, manufacture and processing of agricultural products and its distribution among the final consumers.

The main condition of agro-business activation can become the development of integration processes. Joining up of the enterprises, participating in different kinds of activity in AIC field, allows to use various kinds of resources (manufacturing, financial, investing, human resource, raw materials and others) more effectively, to use the scientific technical potential, to provide competitiveness of agricultural production and food products.

Integration processes development in agro-industrial complex is a global regularity. Developed countries experience shows that at present only large agro-manufacturing joints, including different forms of manufacturing and trade cooperation (agro-firms, agro-corporations, agro-holdings, agro-concerns and so on), can operate properly.

\subsection{Reasons of the Necessity for the Integration Process in the Field of AIC}

Various directions and forms of integration processes have been developed in Western Europe countries, still the vertical agro-industrial integration has become the most widely spread in the AIC sphere. One of the advantages of this integration type is the enhancement of information exchange, gaining control over critical resources, e.g. over products net cost, noticeable increase of output product quality. 
In the conditions of severe competition, the system of promotion of agricultural production to the consumers obtains a huge meaning. Therefore, some structures are formed in which the manufacturer's vertical integration is actualized with logistics and realization organizations.

At present, the vertical integration processes are being actively developed in the Russian Federation as well. In many cases, large vertically integrated corporations make a decisive contribution to the formation of territorial budgets, investment attraction, filling local markets, development of socio-economic infrastructure. That's why the studying of foreign experience of vertically-integrated transnational corporations' construction and functioning in agro-industrial complex appears especially relevant.

The aim of the presented article is to summarize the world practice and to find out the peculiarities of vertically integrated agro-industrial structures development in the Western European countries.

\subsection{Methods}

Approximately up to 50-60-ies of XX century the agricultural manufacture of Western European countries existed mainly in the form of scattered into small fragments (parcels) of natural and later-of petty economies -style peasant farms.

Industrial revolution and formation of large-scale trade, financial and industrial capital resulted in concentration tendency appearing in all the economics spheres including agricultural one.

Historically, the first integration direction in Western European agriculture was vertical integration, which start was connected with buyers of agricultural products appearing in the villages. They had a certain capital and a possibility to buy a ready set of agricultural products, sort the goods out and sell them. Simultaneously, the buyer informed the producers about the market demands and consumers' preferences. Consequently, he managed the specialization of agricultural manufacture and influenced the technological processes.

The integration interaction developed with time. New processes were introduced into integration interaction, including agricultural raw materials processing and ready production selling to the consumers. The manufacturer of the agricultural production as an element of integrated agro-industrial system was economically dependent in everything connected with specialization, selection, supply and selling, technological politics etc. With this, he formally remained autarkic and legally independent.

Thereby, large integrated structures bring small-scale producers under their influence sphere, subdue them, and organize them in necessary scales.

At the present stage of integration processes in AIC sphere, the most intense development is with the vertical bonds of agricultural manufacturers with industrial enterprises. A vertically integrated company is a holding, which structure of assets includes the shares of participation in enterprises, responsible for two or more stages of manufacturing-commercial circuit, in the scope enough for implementation of factual control over their activity.

Integrated systems are formed on the base of certain principles:

- Technological connection of the subjects providing the volume increase and products competitiveness improvement.

- Necessary financial and material support in joint manufacture organization and activity.

- Existence of management company (integrator), which has the experience of business set-up, investment resources management and possibilities of loans attraction.

- Active participation in production-financial processes of all the structural subdivisions of integrated units under centralized management.

- Creation of economic conditions, providing all the integrated organizations with equal possibilities to achieve good results in their production and household activity.

- The process of involving agricultural producers into vertically integrated structure can be actualized in two ways.

The first way is when agro-industrial integration has the form of a concern, i.e. a trust with the single property and centralized management. In this case, two or more different producing processes can be united (for example, keeping the milk cattle flock and dairy products production). Equally, it can be a joint of enterprises, which have a common value chain. For example, breeding livestock is performed at different farming households, while the products processing and meat products are made at a meat-processing plant, which is an enterprise-integrator

The second way is to sell the finished products through specialized and universal trade commissary units. In this 
case the enterprise-integrator can manage the production volumes and control the production-selling activity of the primary agricultural producer (a farmer).

Depending on the integration growth direction, there are two kinds of vertical integration distinguished in the global practice, both of which are applied in agro-industrial complexes:

- Backwards vertical integration - it supposes control acquirement or control increase over suppliers, i.e. agricultural enterprises-producers.

- Direct vertical integration is expressed in the company expansion by means of control acquirement or control increase over the structures, distributing and selling the products.

A consequence of the interaction of contradictory trends of globalization and localization is coming to a regional economic space other regional corporations, formation in agro regions transregional territorial industrial clusters and inter-horizontal and vertically integrated structures for integrating local structures into broader productive systems - inter-regional, national, cross-country, global - and transforming regions into economic entities of the world economy.

Hence, the vertical agro-industrial integration strengthens the competitive advantages in the same sphere either concerning the raw material sources or concerning the direction of ready products promotion and selling to the final consumers.

The main methods of vertical agro-industrial integration are:

- Consolidation - amalgamation of the integrated enterprise with the mother company as a branch or a subsidiary.

- Grouping - formation of a special structure consisting of the integrated enterprise and the basic company which has the property commitments (shares exchange), or management commitments (including another enterprise directors into the board of directors), or various services commitments (informing/advertising, technologies provision, etc.).

- Target extension - integration is reached by means of supply contract extension aiming at setting the steady long-term relationships.

- $\quad$ Franchising - passing the rights to use the brand, the business-model of the main company to the integrated enterprise, as well as passing other types of property necessary for setting-up and running the business.

The most widely spread form of agro-industrial integration is contracting, i.e. signing up the contracts between the immediate agricultural producers (farmers) and non-agricultural enterprises. Prices, volumes, terms of products supply, sides' obligations concerning materials supply and production means, production quality indexes as well as technological conditions of production are fixed in the contract [11]. As a rule, the contracts are negotiated for the term of 5-10 years, which provides the partners with stable long-term business relationships.

Another direction of agricultural production concentration is agricultural cooperation, which supposes the uniting of separate peasant households in separate kinds of manufacture processes. Organizational-economical result of the agricultural cooperation and that of the vertical integration is the same. The difference lies in diametrically different direction of these processes: vertical integration is actualized top down, (often ignoring the interest of primary producers), while agricultural cooperation is a bottom-up process and takes into consideration the maximum of peasant households interest.

\section{Results}

2.1 Development Indicators of the Agricultural Sector in the EU Countries

EU is the leading producer of milk, swine, cattle and corn in the world. Table 1 shows the main products, produced in the EU, and their share in the global production.

Table 1. Main kinds of agricultural products, made in the EU, and their share in the global production

\begin{tabular}{|c|c|c|c|c|c|}
\hline \multirow[t]{2}{*}{ Product } & \multicolumn{2}{|c|}{ EU countries } & \multicolumn{2}{|c|}{ The whole world } & \multirow{2}{*}{$\begin{array}{l}\text { EU share in } \\
\text { the global } \\
\text { production, } \\
\%\end{array}$} \\
\hline & $\begin{array}{l}\text { Volume of } \\
\text { goods } \\
\text { production } \\
\text { billion \$ }\end{array}$ & $\begin{array}{l}\text { Production volume, } \\
\text { billion, tons }\end{array}$ & $\begin{array}{l}\text { The volume of } \\
\text { commodity output } \\
\text { billion } \$\end{array}$ & $\begin{array}{l}\text { Production volume, } \\
\text { billion tons }\end{array}$ & \\
\hline
\end{tabular}




\begin{tabular}{|l|r|r|r|r|r|}
\hline Milk & 45,07 & 150996 & 187 & 625754 & $24,1 \%$ \\
\hline Pork & 34,10 & 22184 & 167 & 108507 & $20,4 \%$ \\
\hline Beef & 21,53 & 7971 & 169 & 62737 & $12,7 \%$ \\
\hline Paltry & 15,05 & 10567 & 132 & 92730 & $11,4 \%$ \\
\hline Gapes & 12,31 & 21543 & 38 & 67067 & $32,1 \%$ \\
\hline Wheat & 12,25 & 136081 & 79 & 671497 & $20,3 \%$ \\
\hline Potato & 7,53 & 54564 & 59 & 365365 & $14,9 \%$ \\
\hline Tomatoes & 5,55 & 15159 & 55 & 161794 & $9,4 \%$ \\
\hline $\begin{array}{l}\text { Chicken } \\
\text { egg }\end{array}$ & 5,51 & 6648 & 32 & 66373 & $10,0 \%$ \\
\hline Apples & 4,61 & 10982 & 54 & 76379 & $14,4 \%$ \\
\hline Corn & 1,56 & 59358 & 872792 & $6,8 \%$ \\
\hline
\end{tabular}

In 2012 EU agricultural households produced about 159,4 billions euro of added value, which makes 1,4\% of the total EU economy added value. Nevertheless, in the period of 2002-2012 the input of agriculture decreased from $1,8 \%$ to $1,2 \%$.

11,3 million of people older than 15 years are employed in the EU agriculture (1,1 million people of them are older than 65 years), which makes 5,2\% of all employed people in the EU countries. The agricultural census fixed that 23,5 million people out of 25,5 million people working in the agricultural sphere permanently, were either the owners or the owners' family members.

There's a striking contrast between the regions in western and eastern EU parts from the point of view of productivity. The highest working efficiency (over 45000 EUR) is fixed in the Netherlands and in different regions of France and Great Britain which are specialized in growing plants. The low agricultural labour productivity (less than 5000 EUR) was demonstrated by Poland, Bulgaria, Romania, Portugal and Slovakia.

According to Eurostat the general amount of agro-holdings in EU countries in the period of 2003-2010 years fell by $18,5 \%$ and by the end of year 2010 made 12,2 thousand of units (Figure1).

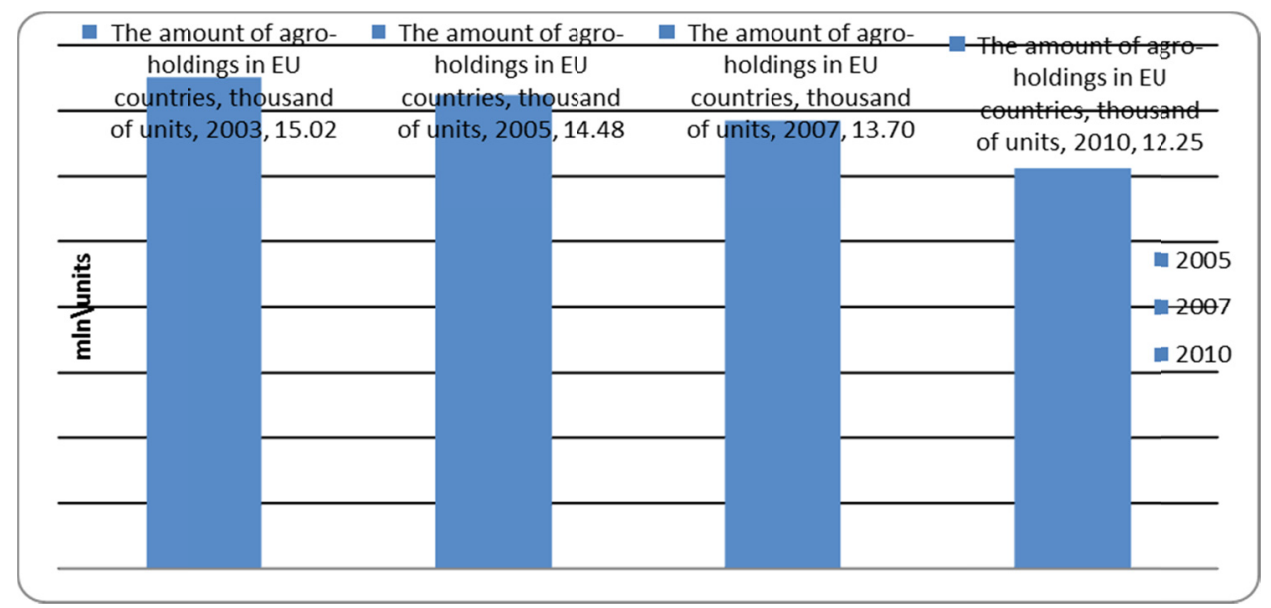

Figure 1. The dynamics of the agro-holdings number in EU countries in 2003-2010

The most rapid decrease $(-35 \%)$ was demonstrated by livestock-breeding agro-holdings, taking $56 \%$ of all agricultural land: their number by the end of the year 2010 was $6,7 \mathrm{mln}$ of units.

Every fourth agro-holding (24,9\%), in EU households specializes in growing field crops (for example, grain, oilseeds, vegetables). Also even one from five agricultural holding (20.1\%) specializes in permanent crop (vineyards, olive groves and orchards). The holdings, specializing in cattle pasture (milk cows, sheep and other ruminant animals), swine, poultry breeding holdings and mixed livestock-breeding agro-holdings take almost a half of all the EU agrarian (46,7\%).

For the same period there was an even greater reduction (35\%) in the number of livestock farms, occupying $56 \%$ of EU agricultural lands (at the end of 2010 the number of farms was 6.7 million units). At the same time the territory of all used agricultural grounds is $174,1 \mathrm{mln}$. hectares, which makes $40 \%$ of the general EU territory. 
The average size of one household is 14,2 hectares. Half of the grounds used in EU agriculture is cultivated in 4 countries: France (16,0\%), Spain (13,6\%), Great Britain $(9,7 \%)$ and Germany $(9,6 \%)$. One fourth of other territories of agricultural grounds (23,3\%), are in Poland, Rumania and Italy, (figure 2).

Still one can observe harsh contrasts in the structure of agriculture in EU countries. On the one hand, there's a huge amount ( $6.0 \mathrm{mln}$. or a half of all the agro-holdings) of very small households (less than 2 hectares) which take a small share $(2.5 \%)$ of the total grounds used for agriculture. And on the other hand, a small amount $(2,7 \%$ of all the agro-holdings) - are very large farms (more than 100 hectares) which cultivate almost a half $(50,2 \%)$ of all the EU agricultural grounds.

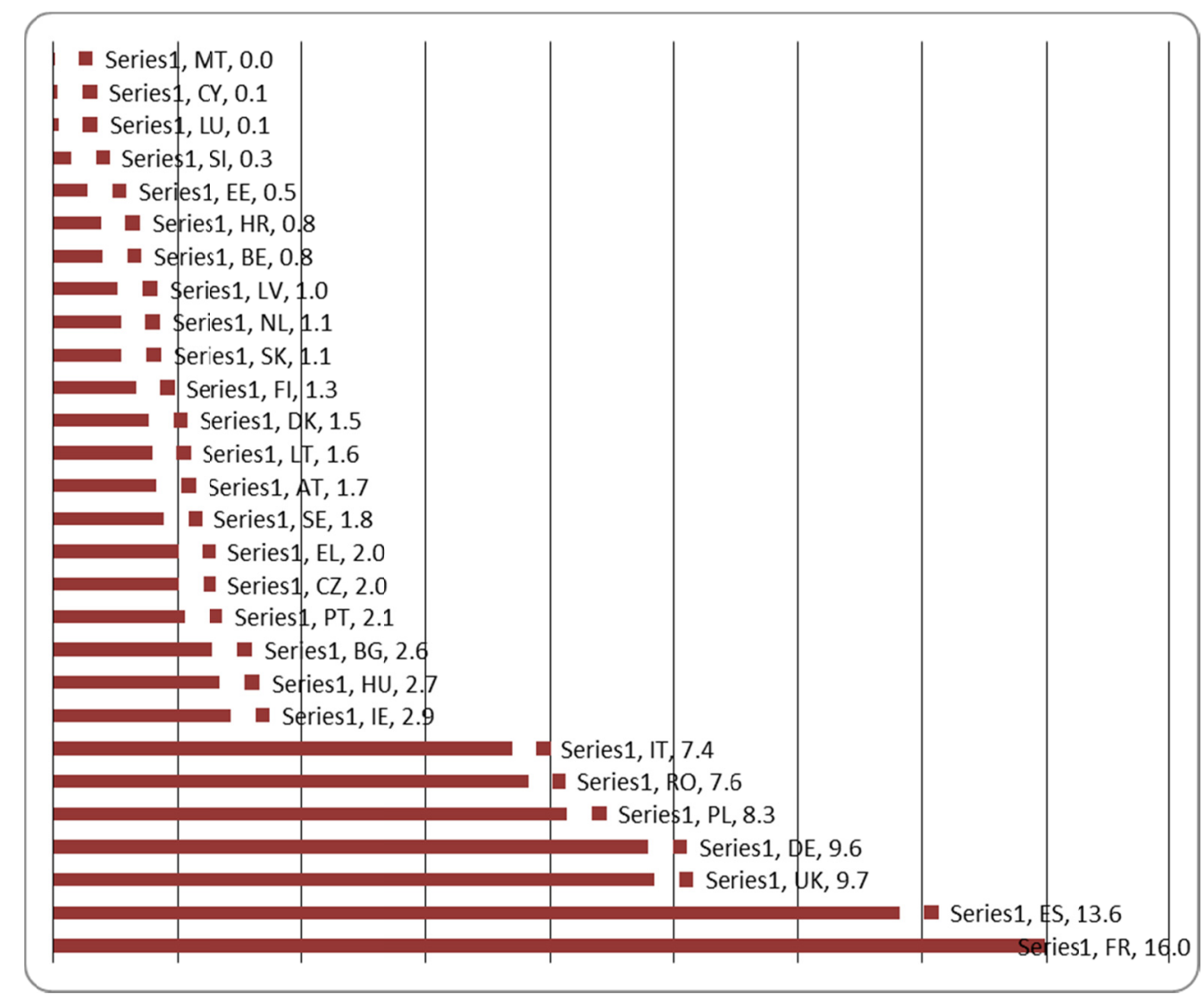

Figure 2. The structure of used agricultural grounds in EU countries-28, \%

However, there are significant contrasts in the structure of agriculture in the EU. On the one hand, there are a large number of agricultural holdings (6.0 million.), consisting of very small farms (of less than 2 ha each) that occupy a small fraction of the total land area $(2.5 \%)$. On the other hand, a small number of agricultural holdings $(2.7 \%)$ are very large farms (with an area of over 100 hectares of farmland), treated with almost the half (50.2\%) of farmland in the EU.

Almost a third (31.5 \% or 3.9 mln.) of all the agro-holdings in EU was in Rumania (figure 3).

These agro-holdings can be characterized as small ones: three fourth of Rumania private grounds were 2.0 hectares big. Italian agricultural enterprises can be called small too (their share in the total number of EU households is $13,2 \%$ ) while Polish households make $12,3 \%$ - their size is on average 10,0 hectares.

At the same time there are quite a number of states -EU members in which larger agro-holdings are more typical. The majority of German households (53,9\%), French (54,4\%), Dutch (55,1\%), Finnish (57,0\%), Irish (57,8\%), UK $(61,4 \%)$ and Luxemburgish $(65,5 \%)$ were larger than 20 hectares. The average size of an agricultural holding in Great Britain is indeed 6 times larger (90,4 hectares) than in EU on average in 2010 while the average size of holdings in the Check Republic was even larger (152,4 hectares) with the small number of really huge farms. 


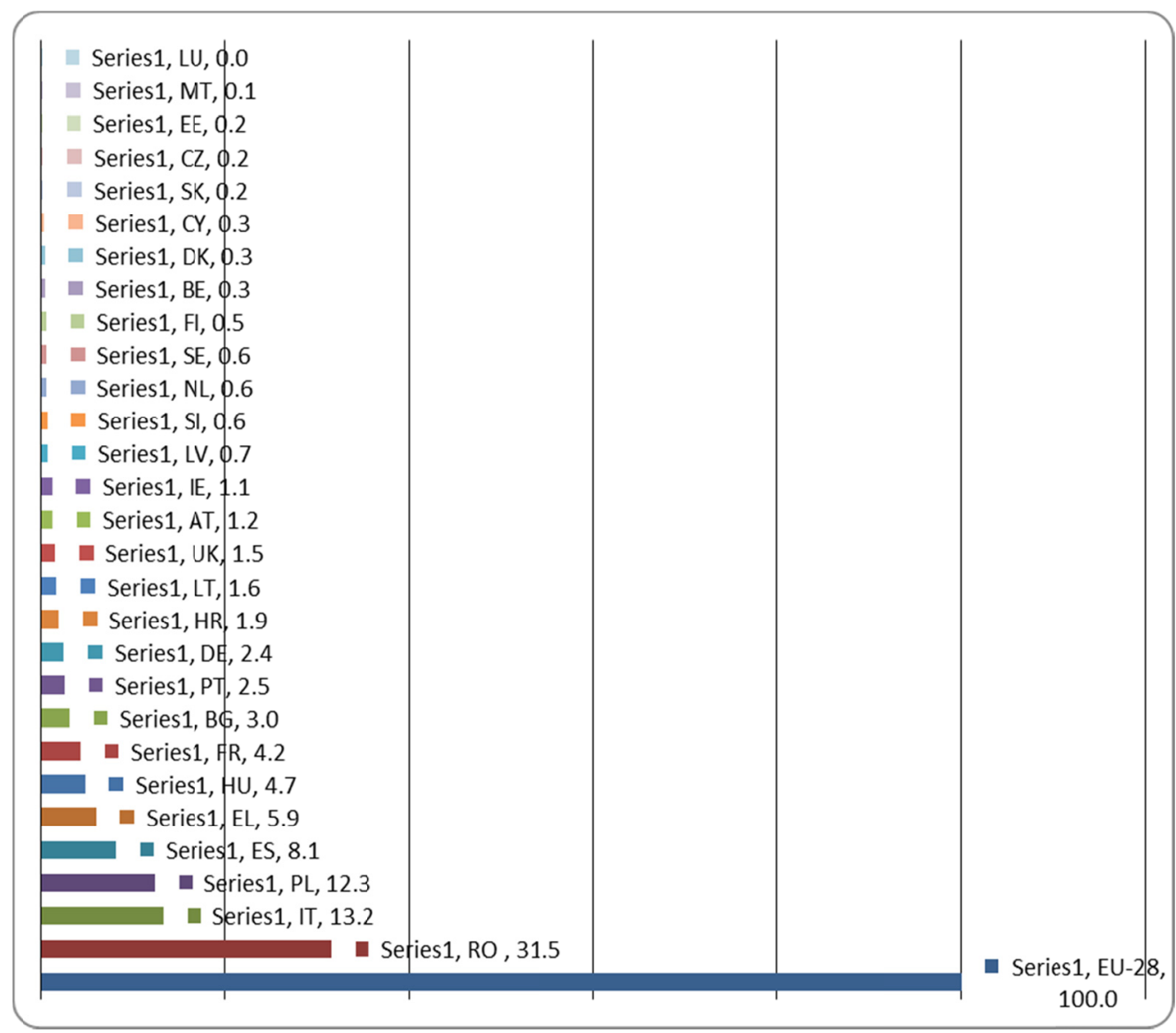

Figure 2. The amount of agro-holdings in EU-28 countries in 2010

This contrast is reflected on holdings' economical results. $5,5 \mathrm{mln}$. of enterprises (44.6\%) out of $12.2 \mathrm{mln}$. of agro-holdings in EU had a standard output of less than 2000 euro and provided only 1,4\% of total agricultural economical manufacture in 2010. The standard output of agricultural products (crops or livestock) in average monetary terms makes the volume of agricultural production in farmers' prices, in euro per hectare or per one beast. On the contrary, $1.9 \%$ of households which had a standard output of more than 250000 EUR, made almost a half (47.8 \%) of all agricultural economical results.

\subsection{The results of the development of the integration processes in the field of agribusiness in EU}

As a result of active integration processes in the agro-business sphere multi-profile transnational joint ventures are being organized. They consist of groups of enterprises, situated on the territory of different countries but under the united management of mother companies such as Unilever (the Netherlands /Great Britain), Anheuser-Busch InBev (Belgium), Nestle (Switzerland), Danone (France), Imperial Tobacco Group, SABMiller, British Foods (the UK), Pernod Ricard (France), Heineken Holding (the Netherlands), Carlsberg (Denmark). Ten largest agro-industrial multinational corporations are presented in Table 2.

Table 2. Top-10 largest agro-industrial multinational corporations in 2013

\begin{tabular}{|l|l|l|l|l|l|l|}
\hline Brand & Country of origin & $\begin{array}{l}\text { sales, } \\
\text { billion. \$ }\end{array}$ & $\begin{array}{l}\text { Profit } \\
\text { billion. \$ }\end{array}$ & $\begin{array}{l}\text { Assets, } \\
\text { billion. \$ }\end{array}$ & $\begin{array}{l}\text { Market value, } \\
\text { billion. \$ }\end{array}$ & $\begin{array}{l}\text { Staff, thousand } \\
\text { people }\end{array}$ \\
\hline "Nestle" & Switzerland & 100,6 & 11,6 & 134,6 & 233,8 & 339 \\
\hline Unilever & $\begin{array}{l}\text { The } \\
\text { Netherlands/Great } \\
\text { Britain }\end{array}$ & 67,7 & 5,9 & 59,9 & 117,8 & 172 \\
\hline
\end{tabular}




\begin{tabular}{|l|l|l|l|l|l|l|}
\hline Danone & France & 27.5 & 2,2 & 38.1 & 44,2 & 102,4 \\
\hline $\begin{array}{l}\text { Associated } \\
\text { British Foods }\end{array}$ & $\begin{array}{l}\text { The United } \\
\text { Kingdom }\end{array}$ & 19,8 & 0,9 & 16,2 & 22,9 & 106,2 \\
\hline $\begin{array}{l}\text { British American } \\
\text { Tobacco }\end{array}$ & $\begin{array}{l}\text { The United } \\
\text { Kingdom }\end{array}$ & 24,7 & 6,2 & 43,9 & 103,2 & 87,5 \\
\hline $\begin{array}{l}\text { Heineken } \\
\text { Holding }\end{array}$ & The Netherlands & 24,3 & 3,9 & 46,7 & 43,5 & 76,2 \\
\hline SABMiller & $\begin{array}{l}\text { The United } \\
\text { Kingdom }\end{array}$ & 16,9 & 4,3 & 55,2 & 84,3 & 77,1 \\
\hline $\begin{array}{l}\text { Imperial Tobacco } \\
\text { Group }\end{array}$ & $\begin{array}{l}\text { The United } \\
\text { Kingdom }\end{array}$ & 23,7 & 1,07 & 44,4 & 34,1 & 37,2 \\
\hline Diageo & $\begin{array}{l}\text { The United } \\
\text { Kingdom }\end{array}$ & 15.34 & 2,67 & 28.69 & 40.93 & 25,7 \\
\hline Pernod Ricard & France & 10,4 & 1,5 & 33,4 & 33,1 & 18,3 \\
\hline
\end{tabular}

As Table 2 shows, five (not considering the English-Dutch company Unilever) out of 10 largest agro-industrial multinational corporations are from the United Kingdom of Great Britain and Northern Ireland.

The initiator of corporate tradition to control the whole production circuit from growing the raw materials to selling the products to the final consumer is the Unilever Corporation. The company was founded in 1929 by uniting the margarine Union of Holland 'Margarine Uni' and the British soap-producing 'Lever Brothers'.

The first vertically-integrated company Unilever owned the enterprises of processing seeds into oil, packing business, trucking industry, retail net.

Agro-industrial multinationals' structure includes national vertically-integrated companies, distributed according to geographical zones. As a rule, the agricultural sector of multinational corporations' agribusiness relies on the raw material base of the country-recipient.

For example, the Swiss global corporation "Nestle" uses the regional model of interaction with the local farmers in the placement countries. The basis of this model was developed as long ago as 1870. It includes: creation of centers of milk collection providing the quality control and milk safety, its cooling and weighing on the electronic balance; payment for the milk; free technical and veterinary support of milk cattle; providing transport and infrastructure nets; microloans for the farmers ( $25 \mathrm{mln}$ US dollars per year); in-time payment for every milk delivery.

Danone company, specializing in fermented milk products, realized the strategy of absorption of foreign enterprises, aspiring to increase their economic activity and financial productivity indexes by means of vertical concentration.

The organizational structure is largely decentralized. National subsidiaries follow the same corporate strategy and vision but they possess enough independency in making decisions concerning products adaptation to the local consumers' demands in taste, texture and packing.

One of the key elements of the corporation business-strategy is the development of partner relationship with the suppliers. Thus, for example, Danone company uniting with the French Institute of live-stock breeding 'Institut de l'Elevage' and dairy farmers became a company under the name "Le lait de nos éleveurs" (milk of our dairy farms) aiming at public awareness increase concerning the production quality. One more example is the program "Vertical growth" launched in 2012 by the Group of Companies Danone in Russia. Within this program Danone experts provide their suppliers with consulting services, regularly organize studying trainings in Milk Business Academy (MBA). More than 150 managers of dairy farms from different Russian regions have passed this course. Different programs of motivation, including celebration of "Supplier's Day", are implemented.

It is evident from the above-described information that in the conditions of the agricultural market globalization there's such a widely spread form of vertical agro-industrial integration as a transnational corporation, which influences greatly the development of AIC branches and global economy on the whole.

\section{Discussion}

The structure of agriculture in EU countries differs greatly under the influence of such factors as geology, 
landscape, climate and natural resources. It also depends on the variety of regional events, infrastructure and social customs. The formation of integration bonds in EU countries has a number of regional and industry-sector peculiarities.

For example, in Great Britain the most widely spread form of agro-industrial integration is industrial-trade corporations.

In Western Europe countries, including France, the most widely-spread form of integration relationship is a holding. Integration processes in France primarily touch upon the agricultural enterprises, those of food industry and the sphere of food trade.

Cooperatives in dairy sector have the highest degree of vertical integration, which is connected with the necessity of immediate milk processing. Large cooperatives specializing in dairy products are mostly located in the west of France. Milk cooperatives of other regions supply milk to the plants of other enterprises - cooperative unions (mostly of the union "Sodiaal") or private companies.

Vertical integration in the grain sector happens both with sale and processing of farm products and with supply of manufacture means. Feed compounds manufacture is the most widespread sector of all the grain-processing sectors. A deeper grain processing (flour-grinding, malt production, manufacture of bakery semi-finished products) is spread only in large agro-holdings which structure contains processing subsidiaries.

A harsh contrast between large vertically integrated holdings and cooperatives with a short manufacture chain is present in meat industry sector. Vertically integrated holdings realize the whole chain including fodder production, cattle slaughter, and meat processing and selling. This kind of integration is typical of poultry and swine farming. For meat cattle sector, cooperatives with a short production cycle (primarily cooperatives of cattle sale) are most typical.

Government plays an important role in formation of integration bonds. The Supreme Council for orientation and coordination of agriculture and food industry development is the organ of inter-sector coordination in food complex of France. It includes Ministry of Finance representatives, manufacturers in the sphere of processing and realization of agriculture products and farmers. Its functions are the development of measures concerning enhancement of food sub-complexes organization and management, pursuing the coherent agricultural and food policy.

In Germany as well as in the countries of central Europe special cooperative state unions are created to smooth the relationships between agricultural enterprises, companies selling agricultural products. Their activity sphere touches upon consultancy work on tax law, cooperation matters, cooperative system subjects representation before legislation organs and society, experience exchange. In order to extend the long-term warranty on keeping rather high purchase prices for agricultural goods in Germany they created the Farmers Union.

Processing enterprises are the integrators in formation of partner relationship between the agriculture and other German trades. It's around them, where the agro-industrial integration is put into practice.

In the countries of Central Europe (Denmark, Norway, Sweden, Finland) the dominating form of agro-industrial manufacture is an agricultural cooperation.

In the Finnish and Swedish agriculture there are Central unions of agricultural manufacturers which work in the close mutual collaboration and provide farmers, authorities, economy, professional unions and population representatives with information. Their activity sphere includes negotiation and development of agreements with the government concerning the problems of agricultural goods supply volume planning, food prices and other questions concerning farms profits.

Agricultural cooperatives have the decisive role in working out and performing the state agrarian policy. Subsides to support agriculture are transferred through them. It so happened that agricultural cooperatives have become the most effective form of Scandinavian countries' agro-business integration. They provide the farms with necessary manufacture conditions; guarantee the sales and efficient introduction of agro-industrial innovations.

This way, the results of research of integration processes development peculiarities in the sphere of EU countries AIC let us state that the most appropriate coordination form of large scale manufactures and small scale farming based on the private land property, is the form of agricultural cooperatives.

It should be noted that in many vertically integrated agro-industrial structures problems of providing organizational and administrative and economic unity, equal benefit of economic relations, responsibility and interest of the participants in the final result of combining the activities of the integrated form, as well as the 
deepening of integration relations are remain unsolved. Overcoming the existing antagonism of economic interests, as well as the disparity of barter relations between agricultural, processing and trading enterprises belonging to the agro holding structure requires scientific study of the system of the inter-economic of the above mentioned integration partners.

Institutional mechanism of AIC diversification is definitely in creation of large vertically integrated agrarian corporations as the most effective form of household organization in AIC. At present, the strengthening of integration processes in agro-industrial complex of European countries is essential for agro-business development. The successfully arranged bond guarantees getting additional cost in agricultural sectors, creating working places and increasing the level of manufacturers' profit.

Petty farmers can't remain the food products only, they'll have to take up an additional role of entrepreneurs and work behind the subsistence farming limits. Besides, agro-industrial companies need reliable local raw material suppliers to increase their international competitiveness.

Modern agro-food system implies intense competitive pressure on all the participants of the cost creation chain. The necessity to respond to the consumers' demands, processers', retailors', transporters' demands imposes stricter and harder demands on the agricultural suppliers from the point of view of quality, terms, processing, transporting. Small producers, representing the main part of global agriculture, nowadays face the growing problem of following these demands.

The question of small farmers' participation in agro-industrial system is not only the question of the system effectiveness but is also one of the key questions of rural inhabitants' welfare level. Exactly for these reasons, the perfection of institutional mechanisms providing the extension of small farms' participation in the modern AIC market must get all the attention of Food and Agriculture Organization of the United Nations [17].

One of such mechanisms is the contracting of agriculture, which includes several aspects, which deserve a separate study and further enhancement: economic, institutional, social, legislative and others.

The advantages from the contract include extension of the approach to the market for the small farms, credits and technologies availability, risk management improvement, agricultural population employment perfection and successful commercial farming.

Now there are five basic models of the interaction of farms and integrator-companies that can define the selection of appropriate mechanisms for the development of contract farming. Enlarged characteristics of basic models of interaction are presented in Table 3.

Table 3. Models of interaction and their characteristics.

\begin{tabular}{|l|l|l|l|l|l|}
\hline Characteristics & $\begin{array}{l}\text { informal } \\
\text { model }\end{array}$ & $\begin{array}{l}\text { Intermediary } \\
\text { model }\end{array}$ & $\begin{array}{l}\text { Multilateral } \\
\text { model }\end{array}$ & $\begin{array}{l}\text { Centralized } \\
\text { model }\end{array}$ & $\begin{array}{l}\text { nucleus } \\
\text { estate model }\end{array}$ \\
\hline Investmentlcredit & never & seldom & seldom & sometimes & sometimes \\
\hline Agroconsulting service & never & sometimes & always & sometimes & sometimes \\
\hline Use of conracts & never & sometimes & always & always & sometimes \\
\hline Farm groups & never & sometimes & sometimes & sometimes & sometimes \\
\hline Growing management & never & seldom & always & sometimes & often \\
\hline $\begin{array}{l}\text { Centralized } \\
\text { productionlprocessing }\end{array}$ & sometimes & sometimes & sometimes & sometimes & always \\
\hline $\begin{array}{l}\text { Postharvest logistics } \\
\text { (packaging, transport) }\end{array}$ & sometimes & seldom & seldom & often & always \\
\hline
\end{tabular}

Informal model - is the most short-term and speculative of all models of interaction with the risk of default for the integrator company, and for the farm. However, it depends on the situation: the interdependence of parties of the contract or long-term trust relationship can reduce the risk of opportunistic behavior. Features of the model:

- Small firms enter into a simple, informal contract for seasonal production with smallholders.

- Often, success depends on the availability and quality of external contacts

- Typical products: requiring minimal processing / packaging, vertical coordination; for example, fresh fruit / vegetables on the local markets, sometimes the main crops.

Intermediary model involves the integrator company to conclude subcontracts with intermediaries (buyers of 
agricultural products, the company aggregators) who work with farmers on the basis of formal or informal agreements. This model can work, if it has good incentives structure and adequate control mechanisms. However, this model has drawbacks for vertical coordination and provision incentives for farmers (integrator company may lose control on production processes, quality control and regularity of supplies, farmers can not benefit from technology transfer; there is also the risk of price distortions and decrease of farmers' level income).

Multilateral model This model can evolve from a centralized or nucleus estate model, for example, after the privatization of parastatals. It includes a variety of organizations, such as government agencies, along with private companies and sometimes financial institutions. Vertical coordination is carried out at the discretion of the integrator company. Proper attention should be paid to the possible risks of political interference. Except the agreement with agrofirm used in this model agreement with the third partyis used, which are service providers (for example, education, loans, deposits, logistics).

Centralized model In this model, the integrator company interacts with a large number of small, medium and large farmers. Participation of integrator can vary from a minimum contribution of a resource (such as certain types of crops) to the control of the most aspects of production (for example, from soil preparation to harvest). Communication and coordination is carried out strictly vertical. Quantities (quota), quality and delivery times are determined at the beginning of the season. Production processes and quality are strictly controlled, sometimes it is directly carried out by employees of the integrator company.

Nucleus estate model In this model, the integrator company provides centralized production and processing on the own real property, complementing their capacity through direct contracts with farmers. Keeping real estate requires a significant investment in land, machinery, staff from the integrator. Model of the nucleus estate usually guarantee deliveries to ensure cost-effective use of installed refining capacity. In some cases, this model is used for research, breeding demonstration purposes and / or as a collection point.

Each of these models of interaction between the integrator company and farmers has a number of advantages and disadvantages (Table 4).

Table 4. Advantages and disadvantages of models of interaction between the integrator company and farmers

\begin{tabular}{|c|c|c|}
\hline Model & Advantages & Disadvantages \\
\hline $\begin{array}{l}\text { informal } \\
\text { model }\end{array}$ & $\begin{array}{l}\text { Virtually no investments from integrator company } \\
\text { in technical / financial support for farmers; } \\
\text { Low operating costs; } \\
\text { high level of supply flexibility }\end{array}$ & $\begin{array}{l}\text { Limited control over production (products, } \\
\text { variety, quality, etc.); } \\
\text { High risk of supply disruptions; } \\
\text { Strong buyer competition. }\end{array}$ \\
\hline $\begin{array}{l}\text { Intermediar } \\
\text { y model }\end{array}$ & $\begin{array}{l}\text { Risk reduction, provided effective control; } \\
\text { Minimum investment in technical / financial } \\
\text { support; } \\
\text { Slight improvement of supply chain management; } \\
\text { Low cost of switching to new partners }\end{array}$ & $\begin{array}{l}\text { Buyer opacity for farmers } \\
\text { Marginal production control (volumes, } \\
\text { quality) }\end{array}$ \\
\hline $\begin{array}{l}\text { Multilateral } \\
\text { model }\end{array}$ & $\begin{array}{l}\text { Limited investment and reduce costs by sharing the } \\
\text { costs between the partners; } \\
\text { Risk reduction (compared to commercial } \\
\text { production) due to geo distribution of agricultural } \\
\text { contractors }\end{array}$ & $\begin{array}{l}\text { High risk of side sales; } \\
\text { No primary production, polnaya dependence } \\
\text { small producers; } \\
\text { High transport costs }\end{array}$ \\
\hline $\begin{array}{l}\text { Centralized } \\
\text { model }\end{array}$ & $\begin{array}{l}\text { Provides a high level of quality control and } \\
\text { production volumes; } \\
\text { Close interaction with farmers holding back } \\
\text { third-party sales }\end{array}$ & $\begin{array}{l}\text { The high level of investment for technical } \\
\text { assistance, as well as pre- and post-harvest } \\
\text { logistics }\end{array}$ \\
\hline
\end{tabular}




\begin{tabular}{|l|l|l|}
\hline $\begin{array}{l}\text { Estate } \\
\text { nucleus }\end{array}$ & $\begin{array}{l}\text { high level of control over the supply chain; } \\
\text { Simplified technical assistance / extension } \\
\text { Low risk of supply disruptions }\end{array}$ & $\begin{array}{l}\text { Requires a significant investment in } \\
\text { production; } \\
\text { Higher risks associated with the harvest; } \\
\text { Limited flexibility in the choice of agricultural } \\
\text { contractors }\end{array}$ \\
\hline
\end{tabular}

The model chosen for the initial phase with the passage of time can and should be adapted and possibly changed to consolidation and extension of scale, respectively, to the higher stage of development.

\section{Conclusion}

Thus, the summary of integration processes practice in AIC of EU countries let us make the following conclusion:

- In the integration process of agricultural, processing and sale companies, the system of contracting has become the most widespread in EU countries.

- In the majority of cases the direct initiators and coordinators are non-agricultural companies, at this the object of integration is agriculture.

- There is active development of various forms and structures of agro-industrial unions (from cooperation to agro-industrial multinationals), which affords to consolidate and use the available resources more effectively.

- Vertically integrated structures with a complete circuit are formed-from the agricultural products producer to its selling to the customers.

- In many European countries, the mechanisms of governmental regulation and support are actively applied in the attempts to develop the agro-industrial market.

Vertical integration allowed to extend the companies activity in AIC. Large agro-industrial corporations of EU countries were formed due to the development of agro-holdings and cooperatives.

\section{References}

Aleshina, T. N. (2010). Agro-industrial integration in the AIC system. Moscow.

Anikina, B. A., \& Rodkina, T. A. (2014). Logistics. Theory and practice. Managing the supply chains. Moscow: Prospect.

Ayusheeva, A. O. (2013). Formation of integrated structures of the regional agro-industrial complex: problems and perspectives. monography. Publish House CENS.

da Silva, C. A., \& Rankin, M. (2013). Contract farming for inclusive market access. Food and agriculture organization of the united nations. Retrieved from http://www.fao.org/uploads/media/cf.pdf

European Commission. (2013). Eurostat regional yearbook. European Union.

Eurostat. (2010). The results of agricultural census of the year. Retrieved from http://epp.eurostat.ec.europa.eu/statistics_explained/index.php/Agricultural_census_2010_-_main_results

FAOSTAT. (2014). Food and Agricultural commodities production. Official site of Statistics Department of Food and Agriculture Organization of UN FAOSTAT. Retrieved from http://faostat.fao.org/site/339/default.aspx

Financial Times Global 500 Rating. Retrieved from http://www.ft.com/indepth/ft500

Food agricultural UN organization (2014). The situation in food and agriculture sphere. Official site FAO from http://www.fao.org/3/a-i4036r.pdf, free

Food agricultural UN organization (2014). The situation in food and agriculture sphere. Official site FAO. Retrieved from http://www.fao.org/3/a-i4036r.pdf

Implementation of the CAP reform. Agriculture and rural development. Retrieved from http://ec.europa.eu/agriculture/cap-post-2013/implementation/index_en.htm

Kerashev, A. A., \& Mokrushin, A. A. (2011). The strategic management of interaction between vertically integrated corporations and regional economic systems of the South of Russia, Bulletin of Adyghe State 
University. Episode 5: The Economy, 3.

Maltseva, I. S. (2013). Cooperation and agro-industrial integration in AIC. Syktyvkar: SLE.

Mokrushin, A. A. (2008). Challenges for intra-economic interaction of subjects of agroholding structures. Scientific Journal KubSAU, 35(1).

Mokrushin, A. A. (2011). The strategic aspects of the interaction of vertically integrated corporations with regional economic system, Bulletin of Adyghe State University. Episode 5: The Economy, 2.

Semykin, V. A., \& Safronov, V. V. (2009). Development effectiveness increase in the agro-industrial complex on the base of realization of its activity diversification strategy. Kursk state agricultural academy Vestnik, 3.

Turyansky, A. V., \& Anichin, V. L. (2010). Agricultural cooperation and agricultural integration: Textbook. 2-nd edition corrected and extended. Belgorod: BelSAA Publish house.

\section{Copyrights}

Copyright for this article is retained by the author(s), with first publication rights granted to the journal.

This is an open-access article distributed under the terms and conditions of the Creative Commons Attribution license (http://creativecommons.org/licenses/by/3.0/). 